Supporting Information

\title{
How Buffers Resist Electrochemical Reactions Induced pH Shift under Rotating Disk Electrode Configuration
}

\author{
Meng-Ke Zhang, Wei Chen, Mian-Le Xu, Zhen Wei, Da Zhou, Jun Cai*, Yan-Xia Chen*
}

Hefei National Laboratory for Physical Science at Microscale and Department of Chemical Physics, University of Science and Technology of China, Hefei, 230026, China

*Email: juncai@ustc.edu.cn, yachen@ustc.edu.cn

Contents:

1. Parameters used in this work

2. Results of model reactions that have reverse evolution trend with the $\mathrm{pH}$ variation

3. Additional figures of model reactions of oxidation in the main text.

4. Concentrations and differentiation of concentrations of buffer pairs with respect to $\mathrm{pH}$

5. Concentration profile within the diffusion layer

6. Applications on several electrochemical energy conversion reactions 


\section{Parameters used in this work}

In this study values of the diffusion coefficient of $\mathrm{D}_{\mathrm{H}^{+}}, \mathrm{D}_{\mathrm{OH}^{-}}, \mathrm{D}_{\mathrm{A}^{-}}$and $\mathrm{D}_{\mathrm{HA}}$ are set to be $9.31 \times 10^{-9} \mathrm{~m}^{2} / \mathrm{s}$, $5.27 \times 10^{-9} \mathrm{~m}^{2} / \mathrm{s}, 1 \times 10^{-9} \mathrm{~m}^{2} / \mathrm{s}$ and $1 \times 10^{-9} \mathrm{~m}^{2} / \mathrm{s}$ respectively. The electrode rotation speed is set to be $\omega=1600 \mathrm{rpm}$. Other parameters are listed in the following Table S1 and S2.

\begin{tabular}{|c|c|c|c|}
\hline Symbols & Physical quantities & Values & Dimensions \\
\hline $\mathrm{F}$ & Faraday constant & 96485 & $\mathrm{C}$ \\
\hline$v$ & Dynamic viscosity of water & $1.1 \times 10^{-6}$ & $\mathrm{~m}^{2} / \mathrm{s}$ \\
\hline$\overline{D_{H}}$ & Diffusion coefficient of $\mathrm{H}^{+}$ & $9.31 \times 10^{-9}$ & $\mathrm{~m}^{2} / \mathrm{s}$ \\
\hline$\overline{\mathrm{D}_{\mathrm{OH}}}$ & Diffusion coefficient of $\mathrm{OH}^{-}$ & $5.27 \times 10^{-9}$ & $\mathrm{~m}^{2} / \mathrm{s}$ \\
\hline $\mathrm{D}_{\mathrm{HF}}$ & Diffusion coefficient of $\mathrm{HF}$ & $1.68 \times 10^{-9}$ & $\mathrm{~m}^{2} / \mathrm{s}$ \\
\hline$\overline{D_{F}^{-}}$ & Diffusion coefficient of $\mathrm{F}^{-}$ & $1.46 \times 10^{-9}$ & $\mathrm{~m}^{2} / \mathrm{s}$ \\
\hline $\mathrm{pK}_{\mathrm{a}}$ & Acidity coefficient of HF dissociation & 3.45 & 1 \\
\hline $\mathrm{D}_{\mathrm{H}_{3} \mathrm{PO}_{4}}$ & Diffusion coefficient of $\mathrm{H}_{3} \mathrm{PO}_{4}$ & $9.59 \times 10^{-10}$ & $\mathrm{~m}^{2} / \mathrm{s}$ \\
\hline $\mathrm{D}_{\mathrm{H}_{2} \mathrm{PO}_{4}^{-}}$ & Diffusion coefficient of $\mathrm{H}_{2} \mathrm{PO}_{4}^{-}$ & $9.59 \times 10^{-10}$ & $\mathrm{~m}^{2} / \mathrm{s}$ \\
\hline $\mathrm{D}_{\mathrm{HPO}_{4}^{2-}}$ & Diffusion coefficient of $\mathrm{HPO}_{4}^{2-}$ & $7.59 \times 10^{-10}$ & $\mathrm{~m}^{2} / \mathrm{s}$ \\
\hline$\overline{\mathrm{D}_{\mathrm{PO}_{4}^{3}}-}$ & Diffusion coefficient of $\mathrm{PO}_{4}^{3-}$ & $8.24 \times 10^{-10}$ & $\mathrm{~m}^{2} / \mathrm{s}$ \\
\hline $\mathrm{D}_{\mathrm{CO}_{2}}$ & Diffusion coefficient of $\mathrm{CO}_{2}$ & $1.91 \times 10^{-9}$ & $\mathrm{~m}^{2} / \mathrm{s}$ \\
\hline $\mathrm{pK}_{\mathrm{a} 1}$ & $\begin{array}{l}\text { First acidity coefficient of phosphoric } \\
\text { acid dissociation }\end{array}$ & 2.16 & 1 \\
\hline $\mathrm{pK}_{\mathrm{a} 2}$ & $\begin{array}{l}\text { Second acidity coefficient of phosphoric } \\
\text { acid dissociation }\end{array}$ & 7.21 & 1 \\
\hline $\mathrm{pK}_{\mathrm{a} 3}$ & $\begin{array}{l}\text { Third acidity coefficient of phosphoric } \\
\text { acid dissociation }\end{array}$ & 12.32 & 1 \\
\hline
\end{tabular}

Table. S1 Parameters used in this work 


\begin{tabular}{|c|c|c|c|c|}
\hline Name of conjugated acid & Molecular formula & Temperature $/{ }^{\circ} \mathrm{C}$ & Dissociation order & pKa \\
\hline oxalic acid & $\mathrm{H}_{2} \mathrm{C}_{2} \mathrm{O}_{4}$ & 25 & 1 & 1.23 \\
\hline sulfuric acid & $\mathrm{H}_{2} \mathrm{SO}_{4}$ & 25 & 1 & 1.92 \\
\hline phosphoric acid & $\mathrm{H}_{3} \mathrm{PO}_{4}$ & 25 & 1 & 2.12 \\
\hline Citric acid & $\mathrm{C}_{6} \mathrm{H}_{8} \mathrm{O}_{7}$ & 25 & 1 & 3.13 \\
\hline hydrofluoric acid & $\mathrm{HF}$ & 25 & & 3.45 \\
\hline formic acid & $\mathrm{HCOOH}$ & 20 & & 3.75 \\
\hline Hydrogen oxalate & $\mathrm{HC}_{2} \mathrm{O}_{4}^{-}$ & 25 & 2 & 4.19 \\
\hline benzoic acid & $\mathrm{C}_{6} \mathrm{H}_{5} \mathrm{COOH}$ & 25 & & 4.21 \\
\hline acetic acid & $\mathrm{CH}_{3} \mathrm{COOH}$ & 25 & & 4.75 \\
\hline Dihydrogen citrate ion & $\mathrm{C}_{6} \mathrm{H}_{8} \mathrm{O}_{7}^{-}$ & 25 & 2 & 4.76 \\
\hline Carbonic Acid & $\mathrm{H}_{2} \mathrm{CO}_{3}$ & 25 & 1 & 6.33 \\
\hline Hydrogen citrate ion & $\mathrm{C}_{6} \mathrm{H}_{8} \mathrm{O}_{7}^{2-}$ & 25 & 3 & 6.40 \\
\hline hydrosulfuric acid & $\mathrm{H}_{2} \mathrm{~S}$ & 18 & 1 & 6.97 \\
\hline Dihydrogen phosphate & $\mathrm{H}_{2} \mathrm{PO}_{4}^{-}$ & 25 & 2 & 7.20 \\
\hline boric acid & $\mathrm{H}_{3} \mathrm{BO}_{4}$ & 25 & & 9.14 \\
\hline Hydrocyanic acid & $\mathrm{HCN}$ & 25 & & 9.31 \\
\hline Bicarbonate & $\mathrm{HCO}_{3}^{-}$ & 25 & 2 & 10.25 \\
\hline hydrogen phosphate & $\mathrm{HPO}_{4}{ }^{2-}$ & 25 & 3 & 12.66 \\
\hline hydrogen sulfide ion & $\mathrm{HS}^{-}$ & 18 & 2 & 12.90 \\
\hline
\end{tabular}

Table S2 Parameters of the most commonly used buffer pairs in electrochemistry

\section{Results of model reactions that have reverse evolution trend with the $\mathrm{pH}$ variation}

All the discussion in the main text and Fig.1-7 are dealing with anodic reactions which produce protons. For cathodic reactions such as HER and ORR, which consume protons, we will have $\mathrm{pHs} \geq \mathrm{pHb}$. For such circumstance, the concentration gradient of proton decreases from the bulk solution toward the electrode surface. The corresponding $\mathrm{j}-\mathrm{pHs}$ diagrams are similar to those of anodic reactions, except that they have reverse evolution trend with the $\mathrm{pH}$ variation. Fig.S1-S7 are the corresponding figure to Fig.1-7 in the main text which are dealing with cathodic reactions. In addition to this, elimination of side effects introduced by buffer species, which is not considered in our model, is also required. For example: 1) Buffer pairs may be very active toward anodic oxidation or cathodic reduction in electrochemical environment, which may interfere with the kinetic analysis of the reactions examined. 2) Buffer pairs, e.g. cations, can strongly adsorb on the electrode, inducing poisoning effects of the electrode reaction. 3) Buffer pairs react with the reactant or the product of the studied reaction. Besides, more complex cases can be that the reactants/products of the studied reaction are also a buffer pair. It is expected that their concentration near the 
electrode surface will change with pHs, reaction current as well as the applied potential. Furthermore, due to the variation of reactants/products' concentration, the reaction pathways and products selectivity may change accordingly. For such system, systematic kinetic simulation will be of great help in unravelling the reaction mechanism and quantifying the selectivity the intrinsic kinetics of respective pathways.
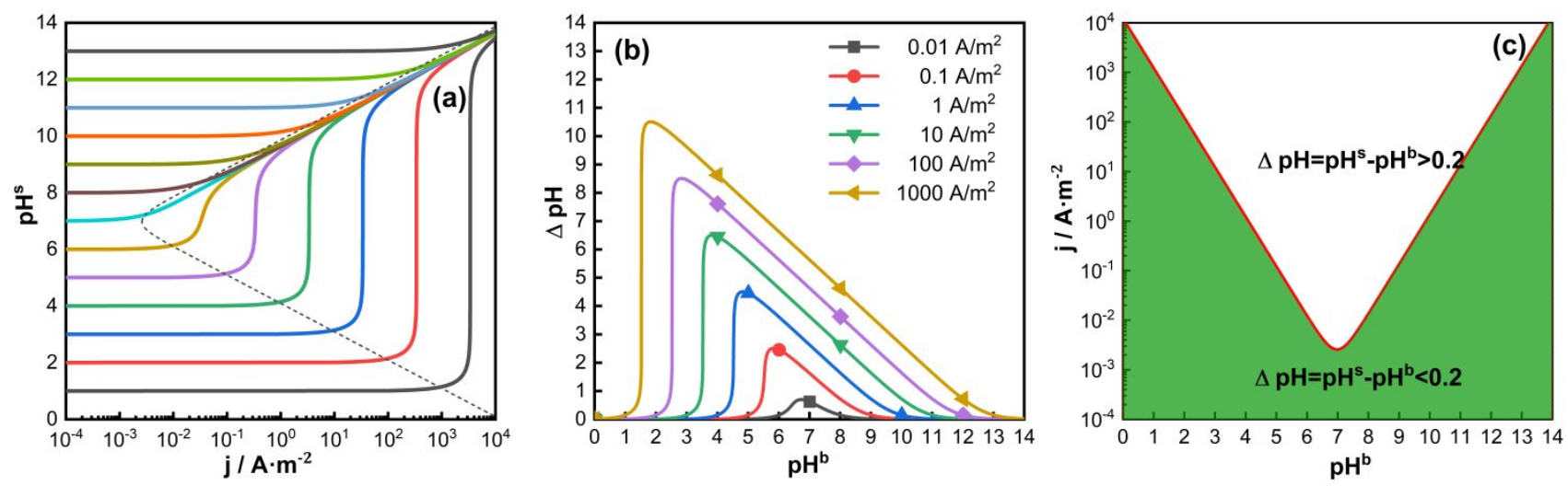

Figure S1. (a) $\mathrm{j}$-pHs plot for reaction 1 at $\mathrm{RDE}$ in solution of different $\mathrm{pH}^{\mathrm{b}}$ (when $\mathrm{j}=0, \mathrm{pH}^{\mathrm{s}}=\mathrm{pH}^{\mathrm{b}}$ ) free of buffer, and the dotted line represents maximum allowable current $\left(\mathrm{j}_{\max }\right)$ with $\Delta \mathrm{pH}=\mathrm{pH}^{\mathrm{s}}-\mathrm{pH}^{\mathrm{b}}=0.2$. (b) The plots of $\Delta \mathrm{pH}$ as a function of $\mathrm{pHb}$ values for reaction 1 at several constant current densities in the range from 0.01 to $1000.00 \mathrm{~A} \mathrm{~m}-2$. (c) The plots of $\mathrm{j}$ as a function of $\mathrm{pH}^{\mathrm{b}}\left(\mathrm{j}_{\max }\right.$ is denoted as red line). $\omega=1600 \mathrm{rpm}$. 


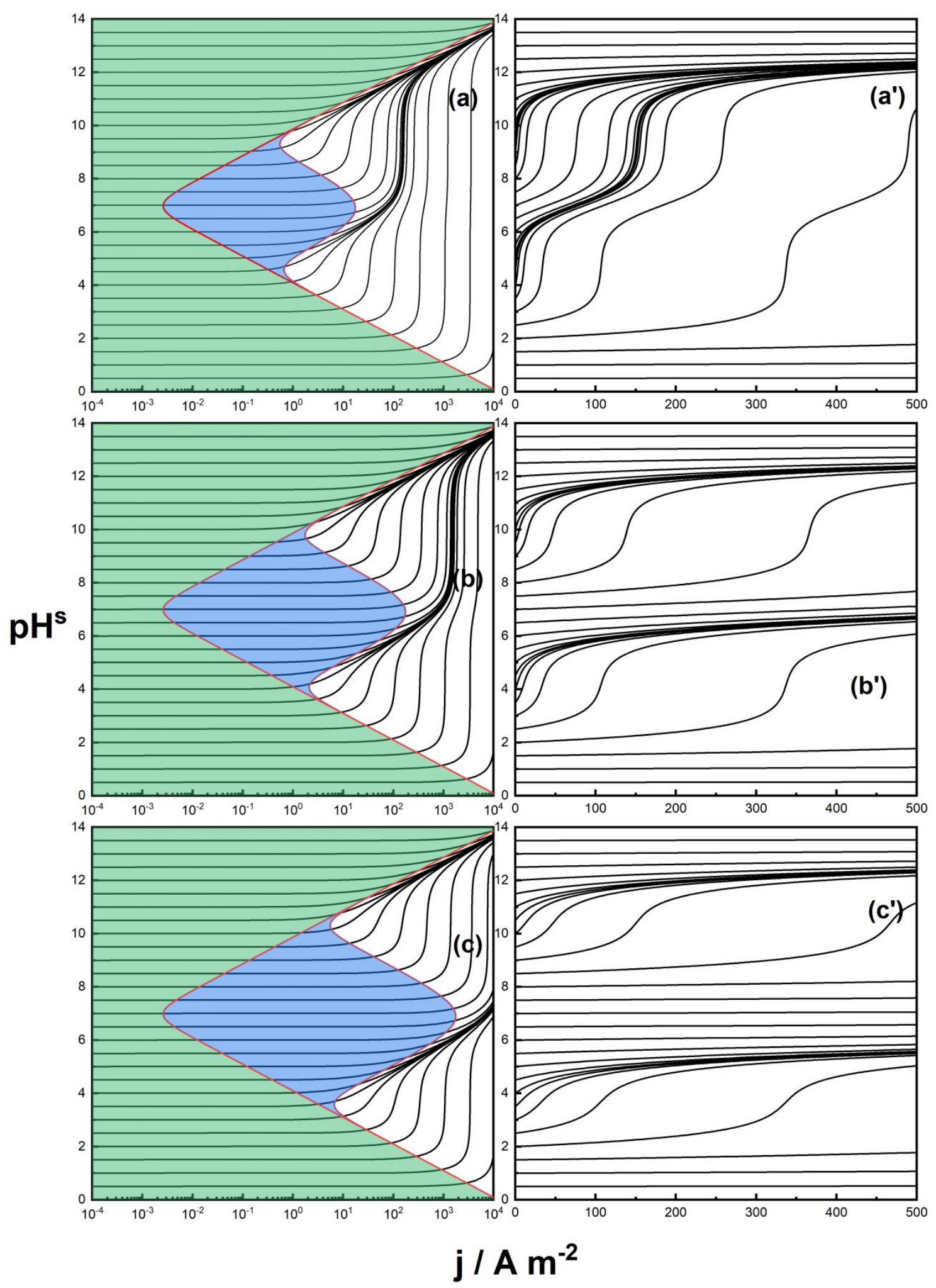

Figure S2. $\mathrm{j}-\mathrm{pH}^{\mathrm{s}}$ plot during reaction 1 in solution of different bulk $\mathrm{pH}^{\mathrm{b}}$ (as indicated in the figure) with HA buffer $(\mathrm{pKa}=7)$ of different overall concentration of the buffer pairs $\mathrm{c}_{0}=[\mathrm{HA}]+\left[\mathrm{A}^{-}\right]$, (a) (a') $0.01 \mathrm{M}$, (b) (b') $0.1 \mathrm{M}$ and (c) (c') $1 \mathrm{M}$, the figures on the right are the corresponding magnification of the $\mathrm{j}-\mathrm{pH}^{\mathrm{s}}$ plots for $\mathrm{j}$ in the range of 0 to $50 \mathrm{~mA} \mathrm{~cm}{ }^{-2}, \omega=1600 \mathrm{rpm}$. 

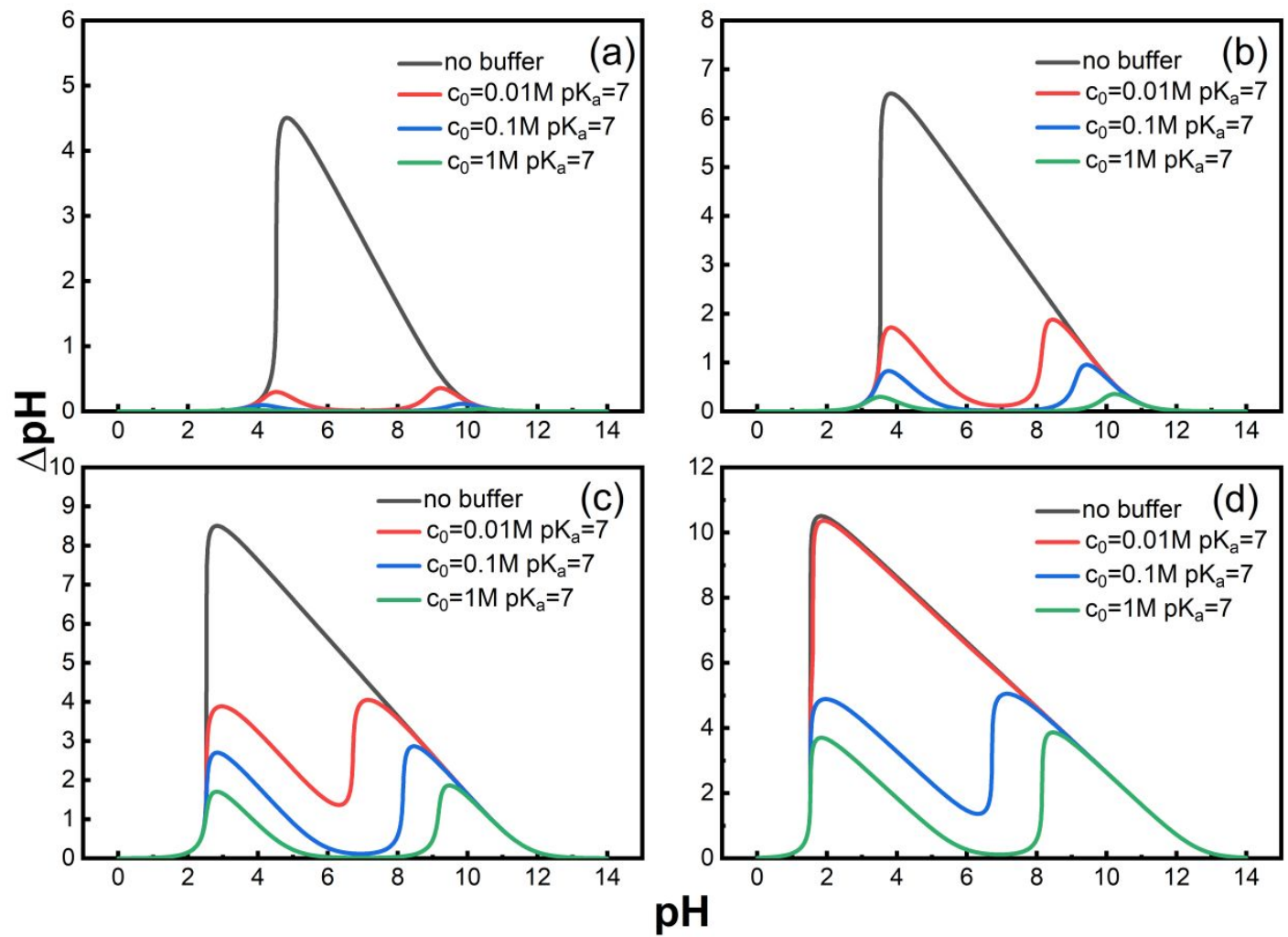

Figure S3. The change of interfacial $\mathrm{pH}^{\mathrm{s}}$ as a function of bulk $\mathrm{pH}^{\mathrm{b}}$ for reaction 1 in solutions of different bulk $\mathrm{pH}^{\mathrm{b}}$ with addition of $\mathrm{x} M$ buffer ( $\mathrm{x}=0.01,0.1$ and 1, $\mathrm{pKa}=7$ ) with at applied current density of (a) 1 (b) 10 (c) 100 and (d) $1000 \mathrm{~A} \mathrm{~m}^{-2}$.

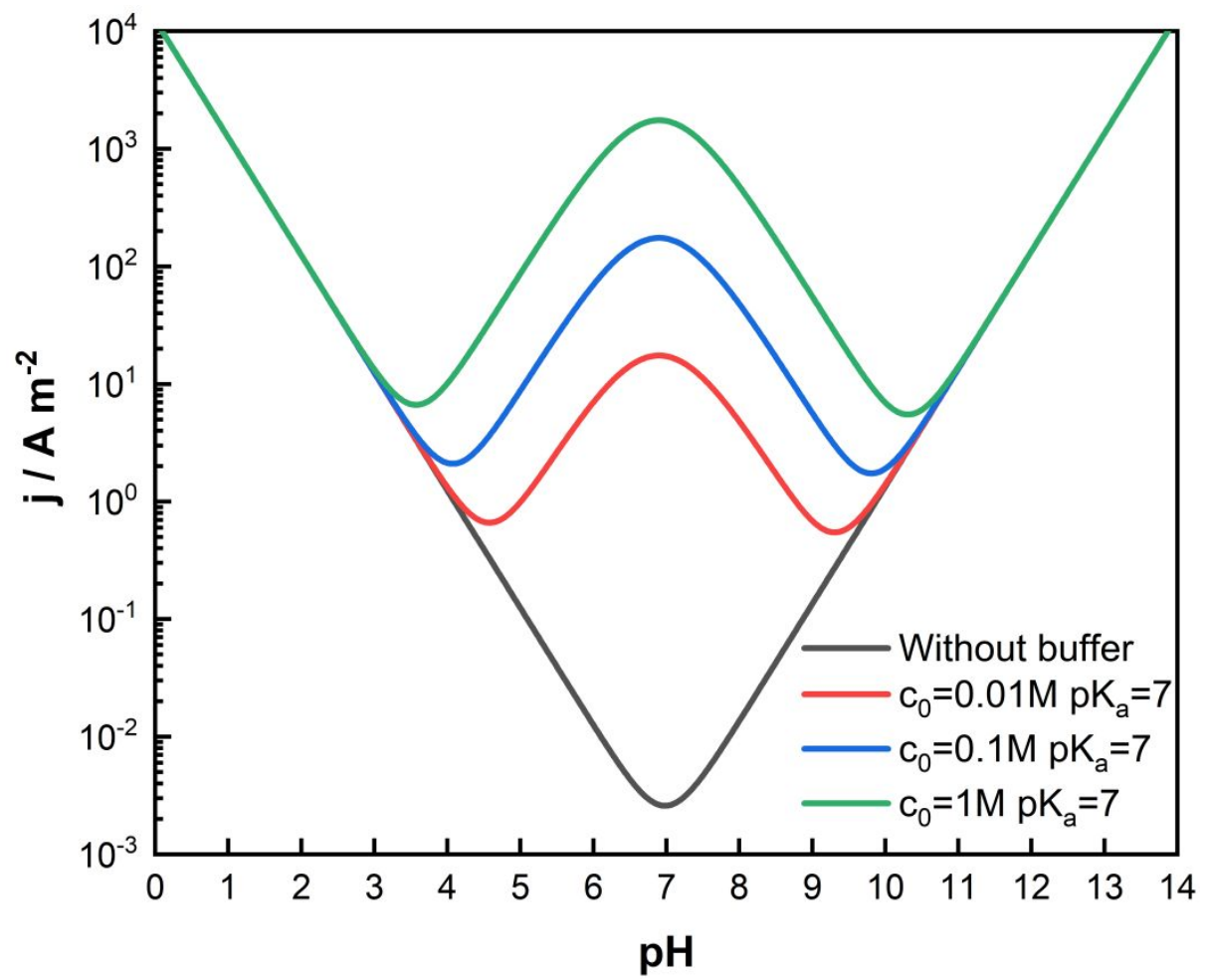

Figure S4. In order to make sure $\Delta \mathrm{pH}=\mathrm{pH}^{\mathrm{b}}-\mathrm{pH}^{\mathrm{s}} \leq 0.2$, the maximum applicable current density for reaction 1 as a function of $\mathrm{pH}$ of the bulk solutions with the addition of $\mathrm{x}$ M buffer whose $\mathrm{pK}_{\mathrm{a}}$ is $7, \mathrm{x}=0.001,0.1,1$. 

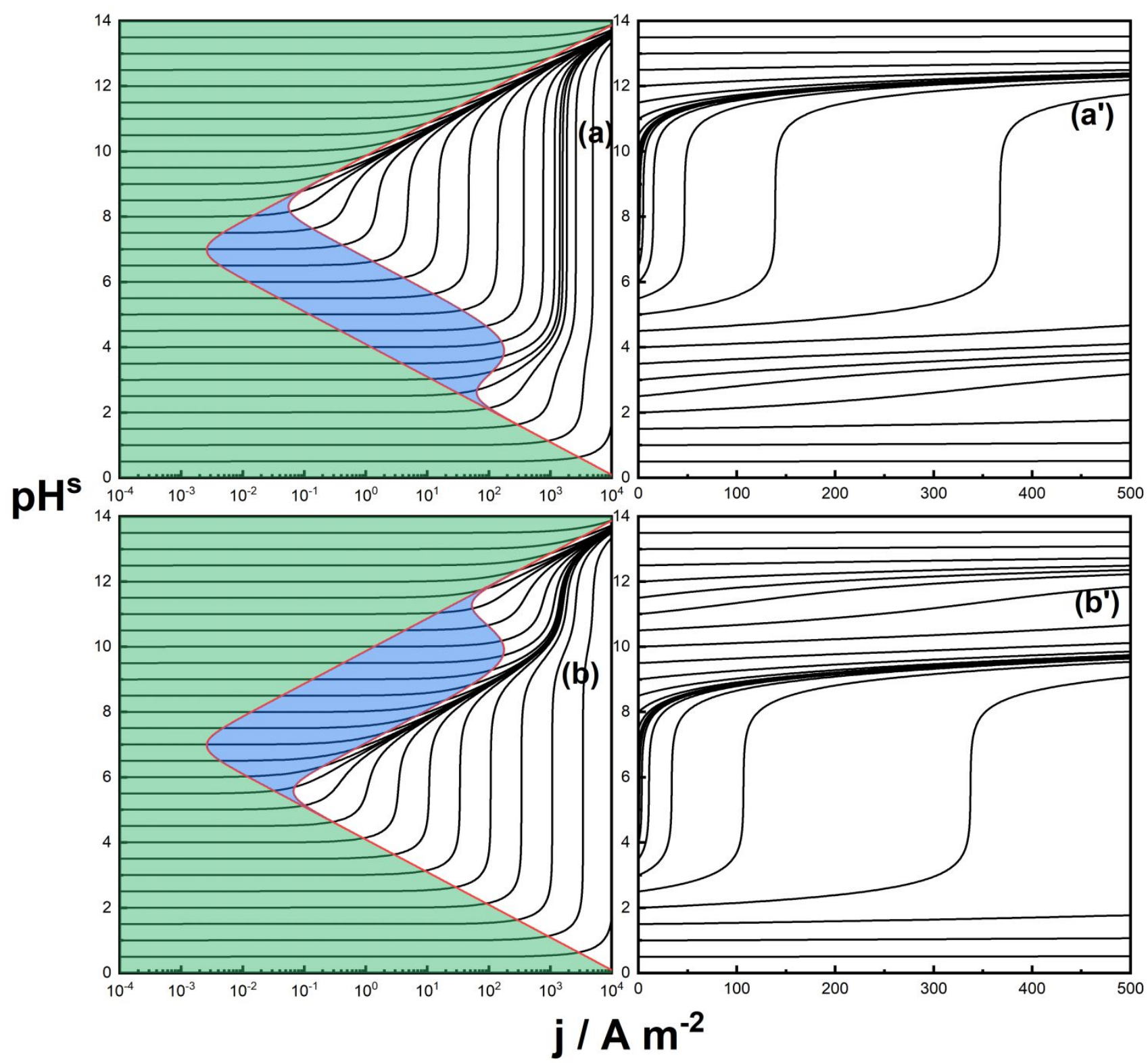

Figure S5. j-pH $\mathrm{pH}^{\mathrm{s}}$ plots during reverse reaction of reaction 1 in solution of different bulk $\mathrm{pH}$ (as indicated in the figure) with $0.1 \mathrm{M} \mathrm{HA} / \mathrm{MOH}$ buffer whose $\mathrm{pKa}$ is $(\mathrm{a})\left(\mathrm{a}^{\prime}\right) 4$ and $(\mathrm{b})\left(\mathrm{b}^{\prime}\right)$ 10, the figures on the right are the corresponding magnification of the $\mathrm{j}-\mathrm{pH}^{\mathrm{s}}$ plots for $\mathrm{j}$ in the range of 0 to $50 \mathrm{~mA} \mathrm{~cm}{ }^{-2}, \omega=1600 \mathrm{rpm}$. 

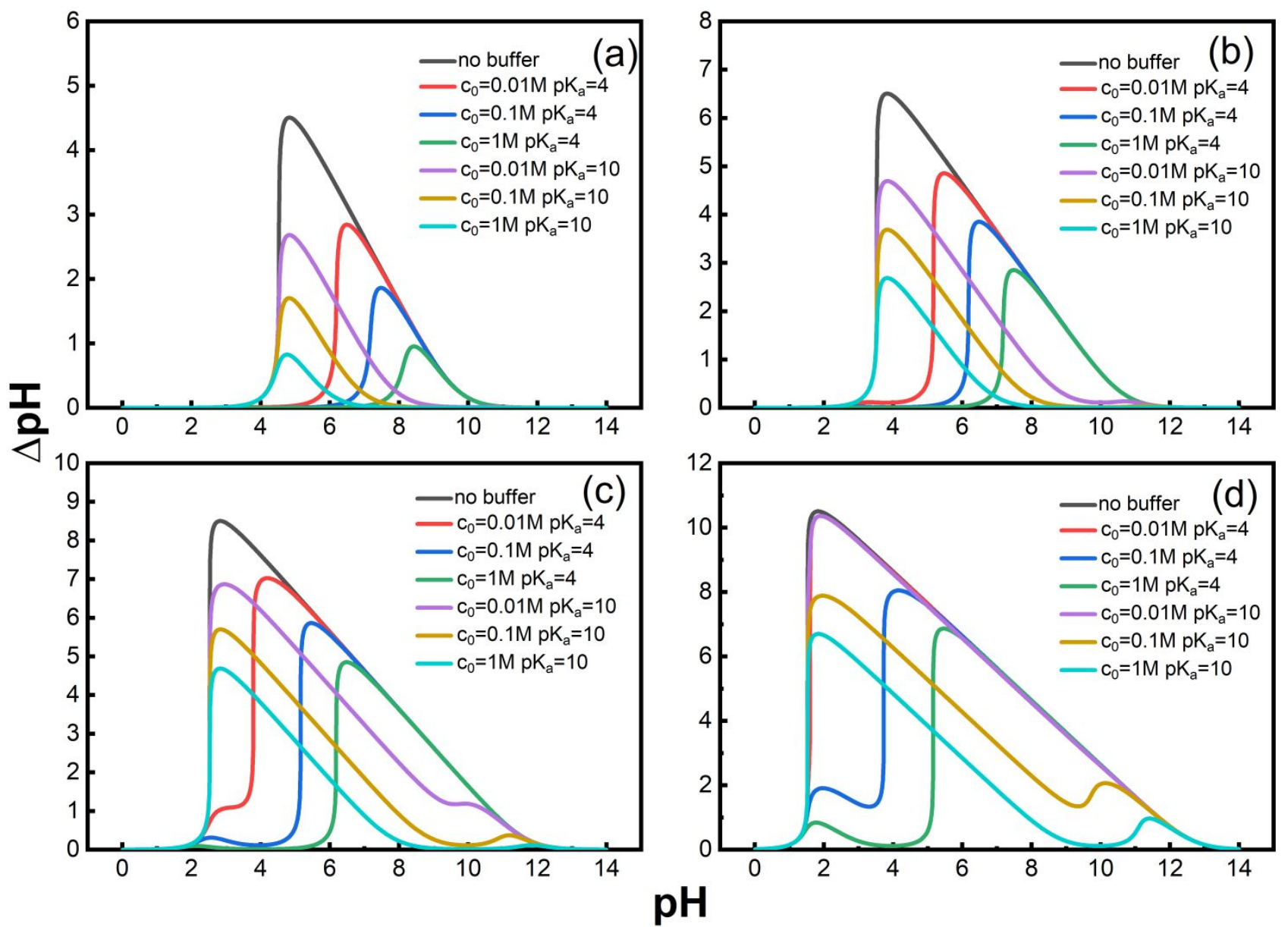

Figure S6. The change of interfacial $\mathrm{pH}$ as a function of bulk $\mathrm{pH}^{\mathrm{b}}$ for reaction 1 in solutions of different bulk $\mathrm{pH}^{\mathrm{b}}$ with addition of $\mathrm{x}$ M buffer ( $\mathrm{x}=0.01,0.1$ and 1 and $\mathrm{pKa}=4$ and 10) under at applied current density of (a) 1 (b) 10 (c) 100 and (d) $1000 \mathrm{~A} \mathrm{~m}^{-2}$.
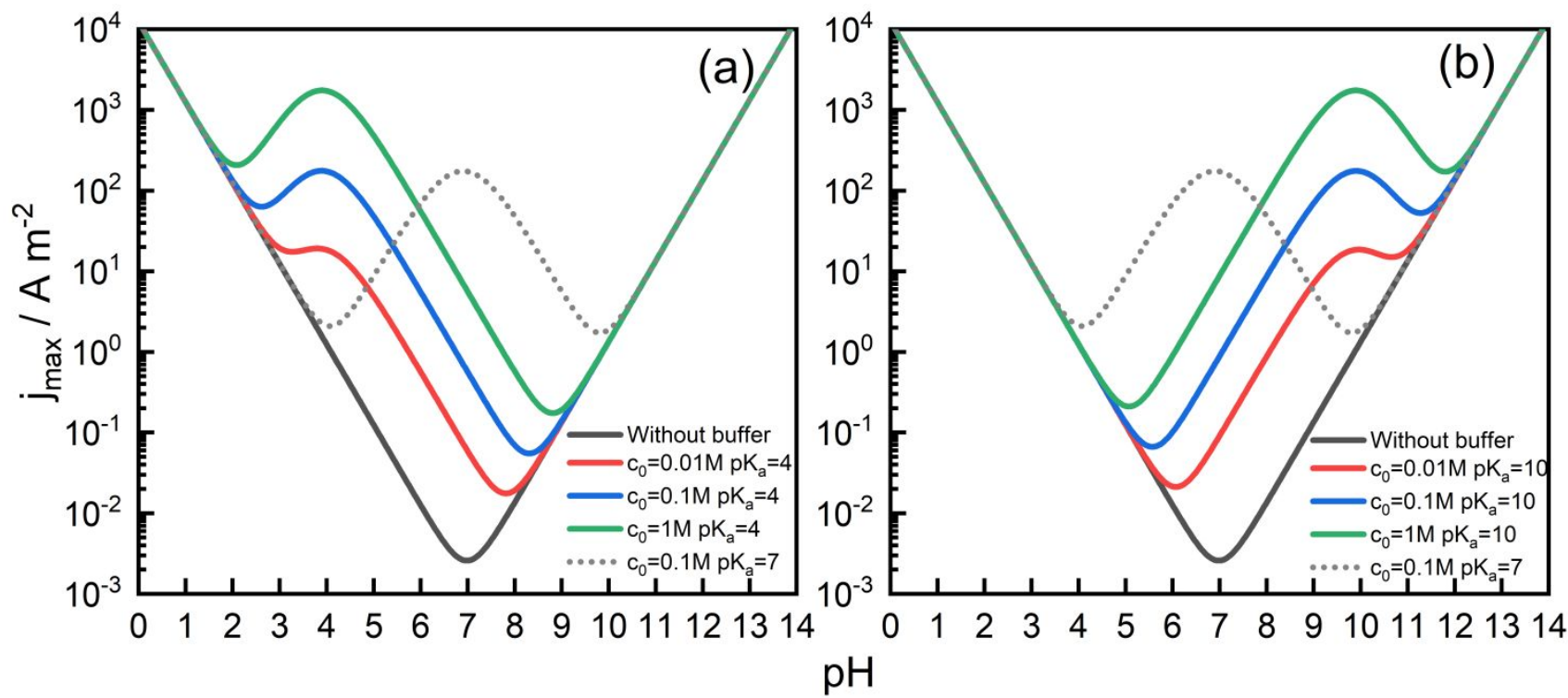

Figure S7. In order to make sure $\Delta \mathrm{pH}=\mathrm{pH}^{\mathrm{b}}-\mathrm{pH}^{\mathrm{s}} \leq 0.2$, the maximum applicable current density for reaction 1 as a function of $\mathrm{pH}$ of the bulk solutions with the addition of $\mathrm{x} \mathrm{M}$ buffer whose $\mathrm{pK}_{\mathrm{a}}$ is (a) 4 (Line with star) and (b) 10 
(solid lines), $\mathrm{x}=0.01,0.1,1$. For comparison, $\mathrm{a} \mathrm{j}_{\max }-\mathrm{pH}^{\mathrm{b}}$ curve with $0.1 \mathrm{M}$ buffer of $\mathrm{pKa}=7$ is also shown (dotted line).

\section{Additional figures of model reactions of oxidation in the main text.}
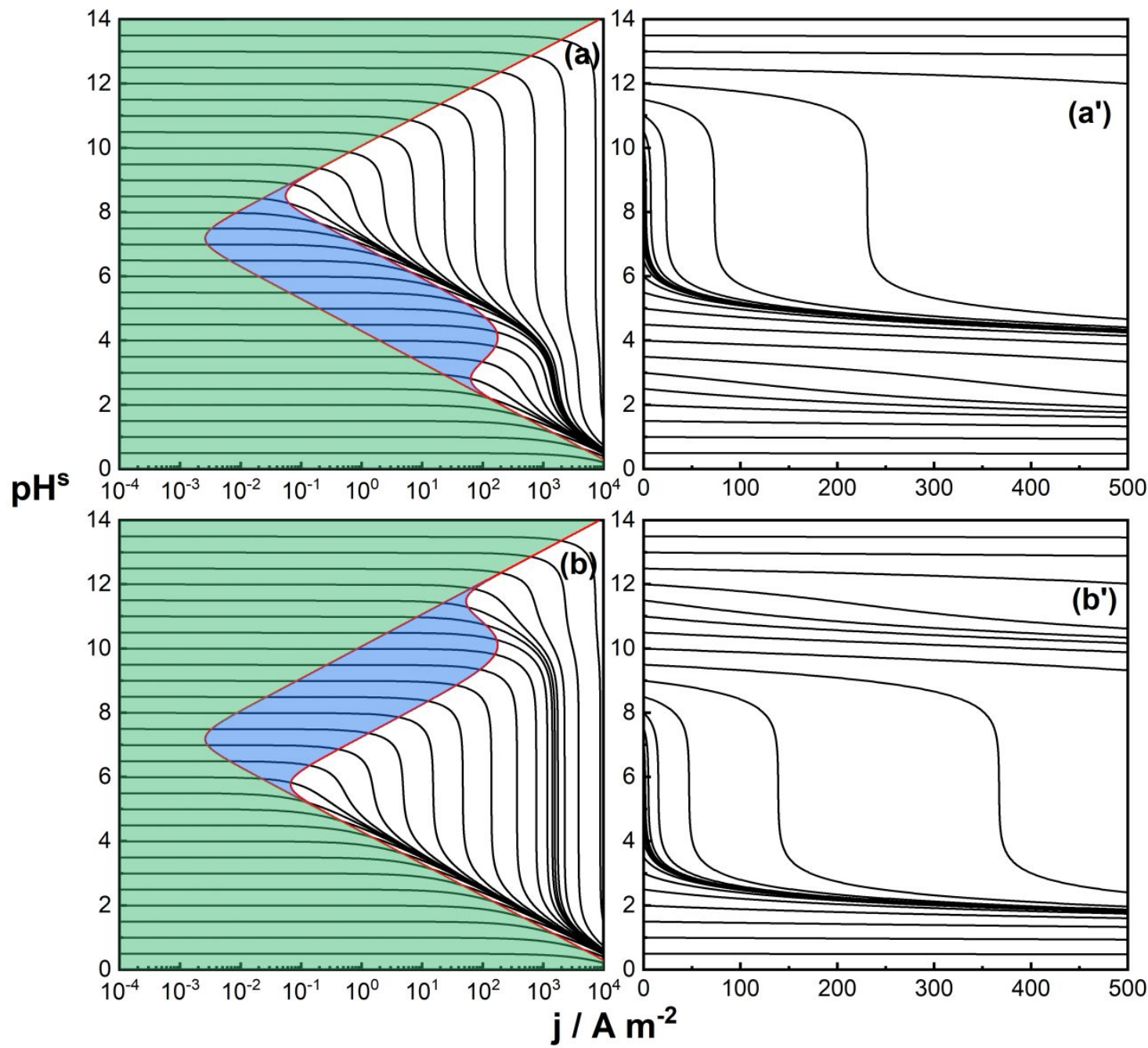

Figure S8. $(\mathrm{a}, \mathrm{b}) \mathrm{j}-\mathrm{pH}^{\mathrm{s}}$ plots for reaction 1 in solution of different bulk $\mathrm{pH}^{\mathrm{b}}$ (as indicated in the figure) with $0.1 \mathrm{M}$ HA/A- buffer whose pKa is (a) 4 and (b) 10. ( $\left.\mathrm{a}^{\prime}, \mathrm{b}^{\prime}\right)$ Enlarged view $\left(0<\mathrm{j}<500 \mathrm{~A} \mathrm{~m}^{-2}\right)$ of the j-pH plots of (a, b), respectively. The green and blue regions are the $\mathrm{j}-\mathrm{pH}^{\mathrm{s}}$ domain satisfies $\mathrm{pH}^{\mathrm{b}}-\mathrm{pH}^{\mathrm{s}} \leq 0.2$ in solutions free of buffer (green) and with addition of buffer (blue), the unmarked region in $(\mathrm{a}, \mathrm{b})$ is the $\mathrm{j}-\mathrm{pH}^{\mathrm{s}}$ domain with $\mathrm{pH}^{\mathrm{b}}-\mathrm{pH}^{\mathrm{s}} \geq 0.2$ even with addition of buffer. Electrode rotation rate $\omega=1600 \mathrm{rpm}$.

Fig.5a display the $\mathrm{j}-\mathrm{pH}^{\mathrm{s}}$ diagram of reaction 1 with the addition of $0.1 \mathrm{M}$ buffer pair $\left(\mathrm{HA} \rightleftarrows \mathrm{H}^{+}+\mathrm{A}^{-}\right)$whose $\mathrm{pKa}$ is 4 .

Fig. S8a' shows the magnification of the part for current density in the range of 0 to $500 \mathrm{~A} \mathrm{~m}^{-2}$ of Fig. S8a. Similar to the case with addition of a buffer whose $\mathrm{pKa}=7$ (Fig. 2), the buffer displays highest buffer capability in solutions whose $\mathrm{pH}^{\mathrm{b}}$ is equal to $\mathrm{pKa}$ of the buffer (Here the buffer effect from HA is superior to water). In solutions whose $\mathrm{pH}^{\mathrm{b}}$ is below 4 , the buffer capability is rather good, flowing of $10 \mathrm{~A} \mathrm{~m}^{-2}$ current density may only induce a drift of $\mathrm{pH}^{\mathrm{s}}$ by ca. $0.2 \mathrm{pH}$ unit (Fig.S8 $\mathrm{a}^{\prime}$ ). In contrast for solutions whose $\mathrm{pH}^{\mathrm{b}}$ is above 5, the buffer capability drops steeply, as a result the lowest buffer capability appears at $\mathrm{pH}^{\mathrm{b}}=8.5$. The maximum applicable current density decays from 100 


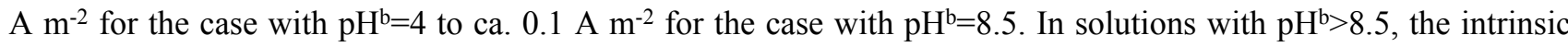
buffer capability increases with the increase of $\mathrm{pH}^{\mathrm{b}}$, this is due to the increase of $\mathrm{OH}^{-}$concentration for the blank solution without buffer. Since the $\mathrm{pKa}$ of the buffer pairs $(\mathrm{pKa}=4)$ added is too far away from the $\mathrm{pH}^{\mathrm{b}}$ and the concentration is low $(0.1 \mathrm{M})$, the contribution of the added buffer in regulating the $\mathrm{pH}^{\mathrm{s}}$ is negligible. As a result, in solutions with $7<\mathrm{pH}^{\mathrm{b}}<10$ significant $\mathrm{pH}^{\mathrm{s}}$ drift occurs when the applied current is higher than $0.1 \mathrm{~A} \mathrm{~m}^{-2}$ (Fig.S8a'). Similar asymmetric enhancement of the buffer capability is also seen for reaction 1 in solutions with addition of 0.1 $\mathrm{M}$ buffer pair whose $\mathrm{pKa}$ is 10 (Fig.S8b and $\mathrm{S} \mathrm{b}^{\prime}$ ). For such case, in solutions with $5<\mathrm{pH}^{\mathrm{b}}<8$, the buffer capability is rather low, because the $\mathrm{pH}^{\mathrm{b}}$ is too far away from the $\mathrm{pKa}$ of the buffer pairs.

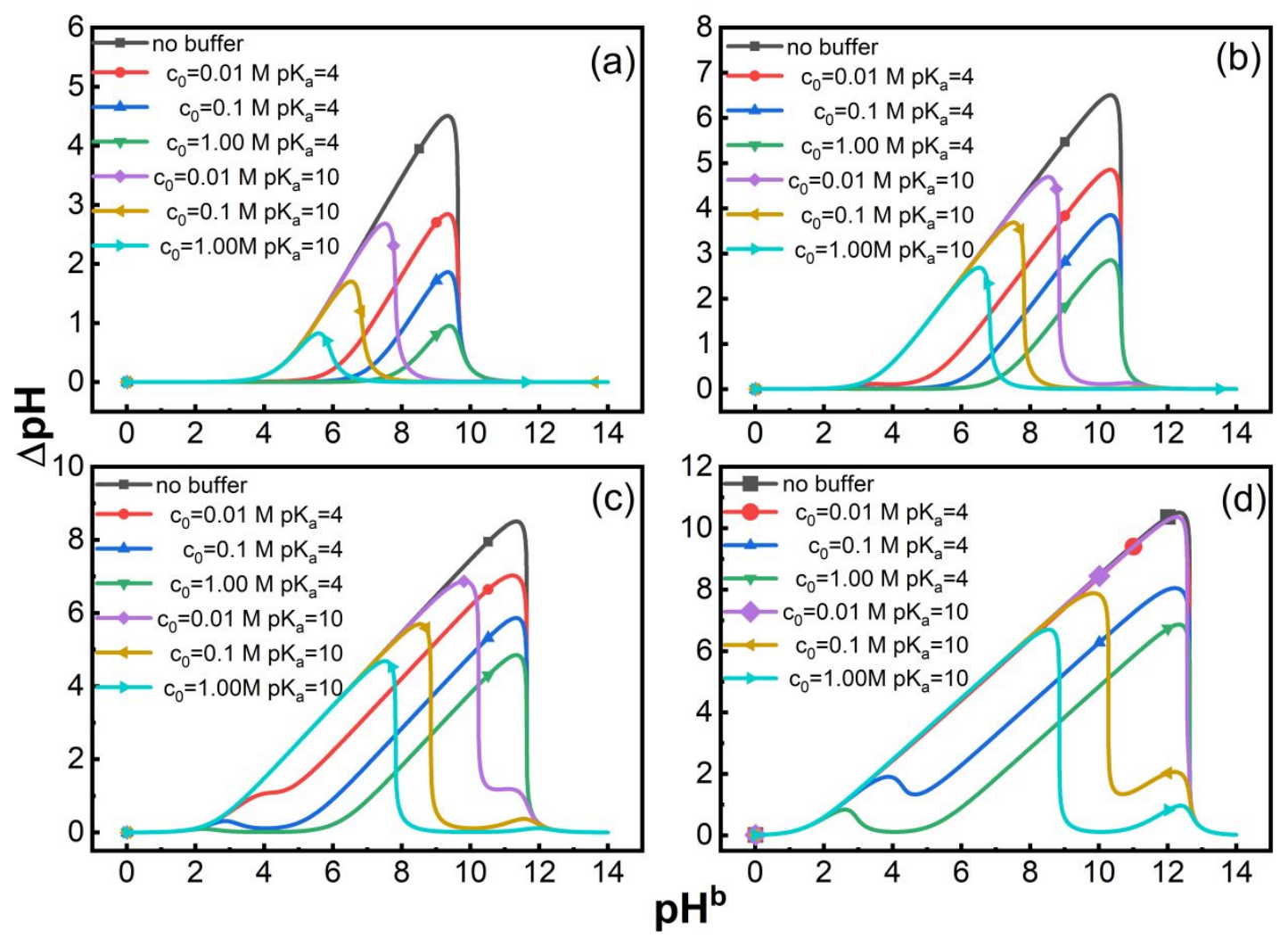

Figure S9. At constant current density of (a) 1 (b) 10 (c) 100 and (d) $1000 \mathrm{~A} \mathrm{~m}^{-2}$, the change of $\mathrm{pH}^{\mathrm{s}}\left(\Delta \mathrm{pH}=\mathrm{pH}^{\mathrm{s}}-\mathrm{pH}^{\mathrm{b}}\right)$ as a function of $\mathrm{pH}^{\mathrm{b}}$ for reaction 1 at a $\mathrm{RDE}$ in solutions of different $\mathrm{pH}^{\mathrm{b}}$ with addition of $\mathrm{x}$ (overall concentration, $\mathrm{x}=0.01,0.10$ and 1.00) $\mathrm{M}$ buffer pair whose $\mathrm{pKa}$ is 4 or 10 . Electrode rotation rate $\omega=1600 \mathrm{rpm}$.

Similar to Fig. 3 and Fig.6 in the main text, The change of $\mathrm{pH}^{\mathrm{s}}$ at the interface from the $\mathrm{pH}^{\mathrm{b}}$ of the bulk solution where the reaction occurring at some applied current densities with the addition of the buffer with concentrations from $0.01,0.10$ and $1.00 \mathrm{M}$ are displayed in Fig. $\mathrm{S} 9$ as a function of the $\mathrm{pH}^{\mathrm{b}}$. If the applied current is just $1 \mathrm{~A} \mathrm{~m}^{-2}$, a buffer with $\mathrm{pKa}=4$ (or 10) and concentration of $0.1 \mathrm{M}$ is enough to sustain the $\mathrm{pH}^{\mathrm{s}}$ at the interface for solutions with $1<\mathrm{pH}^{\mathrm{b}}<6$ (or $\left.8<\mathrm{pH}^{\mathrm{b}}<13\right)$ (Fig. S9). 


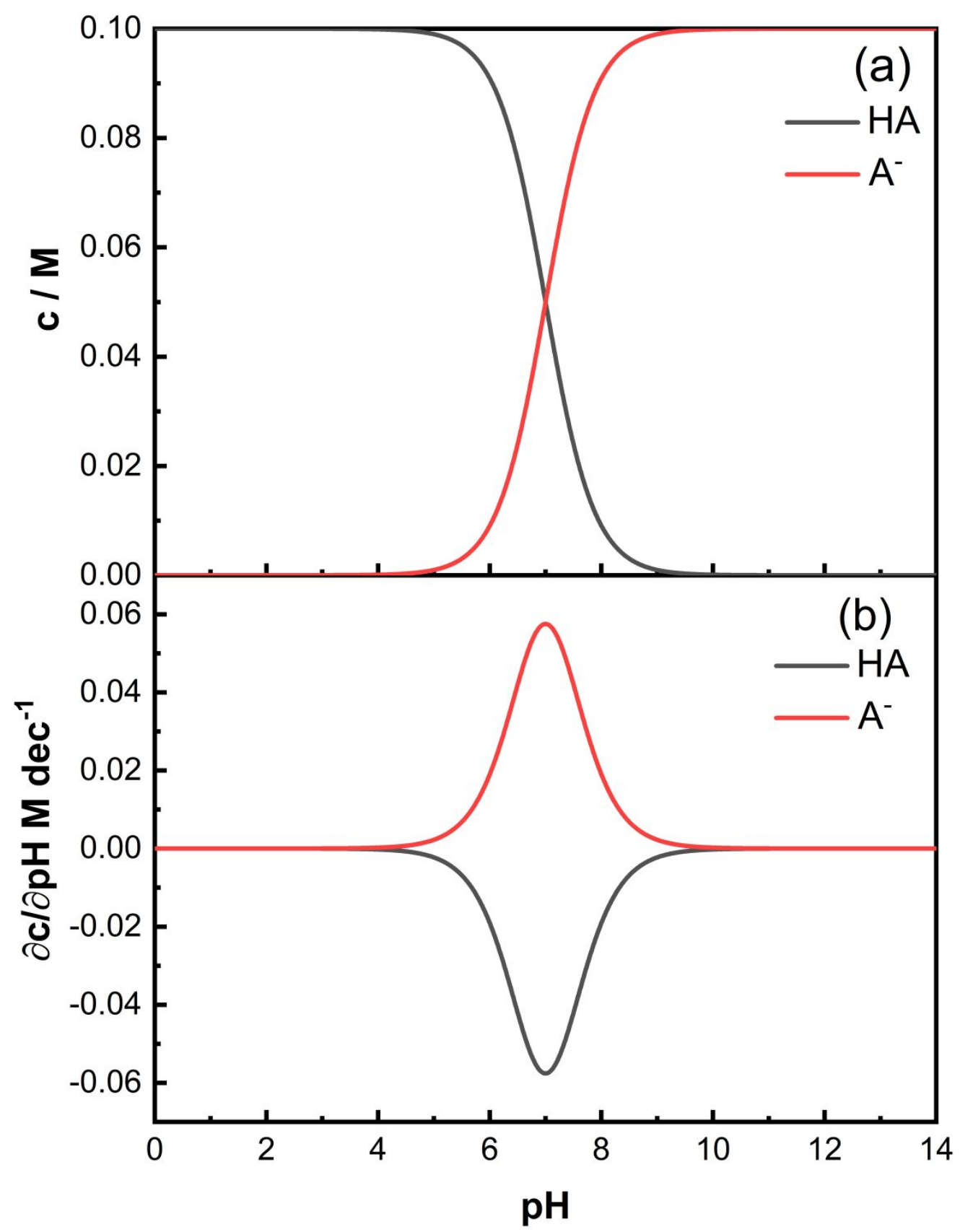

Figure S10. Variation of (a) concentrations of HA (black line) and $\mathrm{A}^{-}$(red line) with $\mathrm{pH}$ and (b) the differentiation of concentrations of $\mathrm{HA}$ (black line) and $\mathrm{A}^{-}$(red line) with respect to $\mathrm{pH}$ in solution of $\mathrm{c}_{\mathrm{HA}}+\mathrm{c}_{\mathrm{A}}=0.1 \mathrm{M}, \mathrm{pKa}=7$. 


\section{Concentration profile within the diffusion layer}

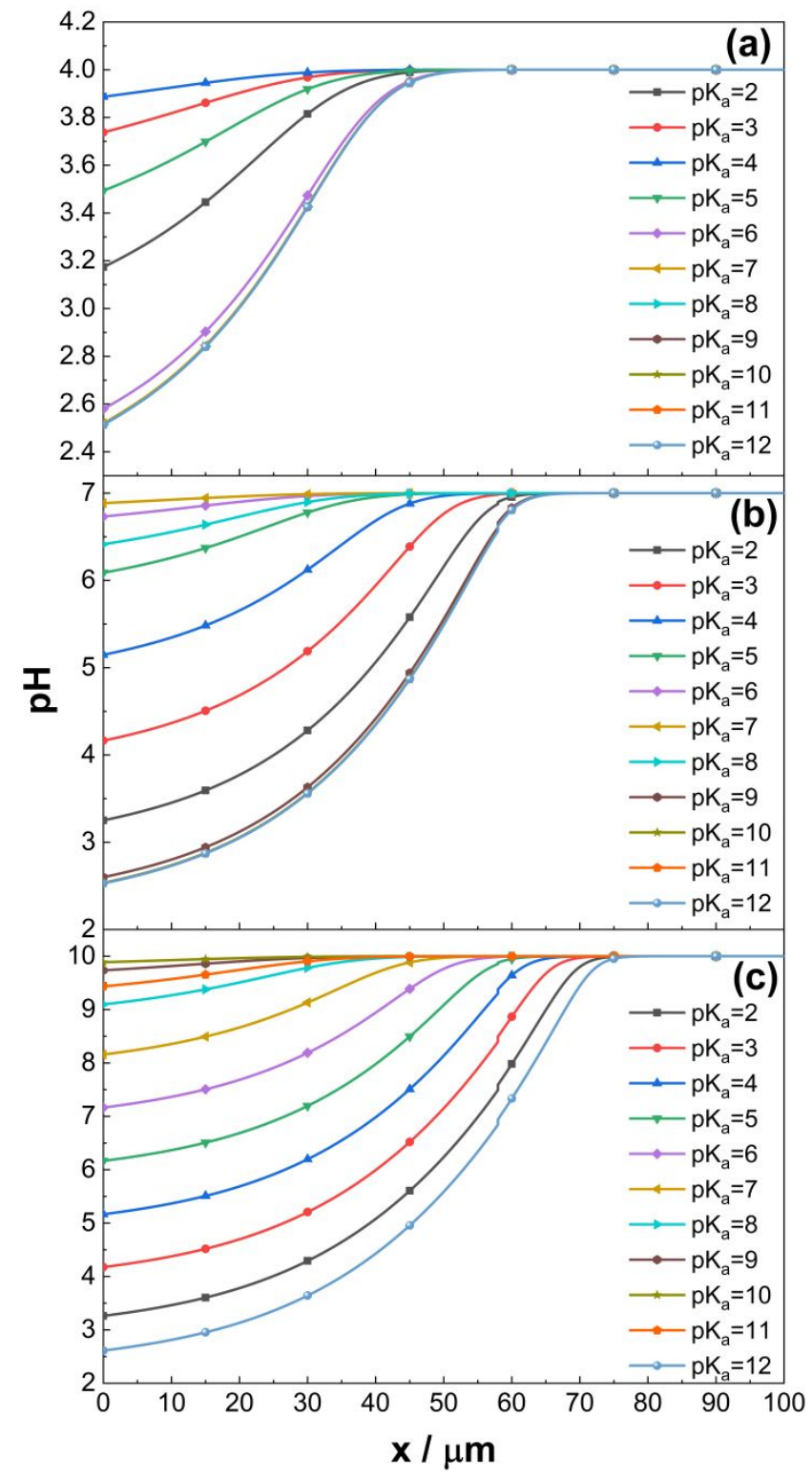

Figure S11. In the solution of $\mathrm{pH}^{\mathrm{b}}=$ (a) 4 (b) 7 (c) 10 , the calculated profiles of $\mathrm{pH}$ as a function of the distance from the electrode surface for reaction 1 . Current density $\mathrm{j}=10 \mathrm{~mA} / \mathrm{cm}^{-2}$. The overall concentration of the buffer pairs, $\mathrm{c}_{0}=[\mathrm{HA}]+\left[\mathrm{A}^{-}\right]=0.1 \mathrm{M}$, and $\mathrm{pKa}$ of the buffers added is from 2 to 12 .

Comparing to the curves shown in Fig. 4 in the main text, we see that under otherwise identical conditions, $\mathrm{pH}^{\mathrm{s}}$ drift in solutions within medium $\mathrm{pH}^{\mathrm{b}}$ for the case with addition of buffers with $\mathrm{pKa}=4$ and 10 is significantly larger than that with $\mathrm{pKa}=7$. This indicates that if one needs to maintain the $\mathrm{pH}^{\mathrm{s}}$ for reactions solutions with $\mathrm{pH}^{\mathrm{b}}$ close to 7 , buffers with $\mathrm{pKa}=4$ and 10 are not good candidates. This is seen more clearly from Fig. S11 where the $\mathrm{pH}$ gradient 
as a function of distance $\mathrm{x}$ to the electrode surface for solutions with different $\mathrm{pH}^{\mathrm{b}}$ and with addition of buffers with $\mathrm{pKa}=4$ or 10 (estimated based on Eq. 18) are much higher than that with $\mathrm{pH}^{\mathrm{b}=7}$. As can be seen from Fig. S11, only if the $\mathrm{pH}$ of solution is equal to $\mathrm{pKa}$ of the buffer added, the gradient of concentration of protons near the surface of electrode would be lowest, thus the buffer ability will be strongest in the solution with $\mathrm{pH}$ equals $\mathrm{pKa}$ of the buffer.

\section{Applications on several electrochemical energy conversion reactions}
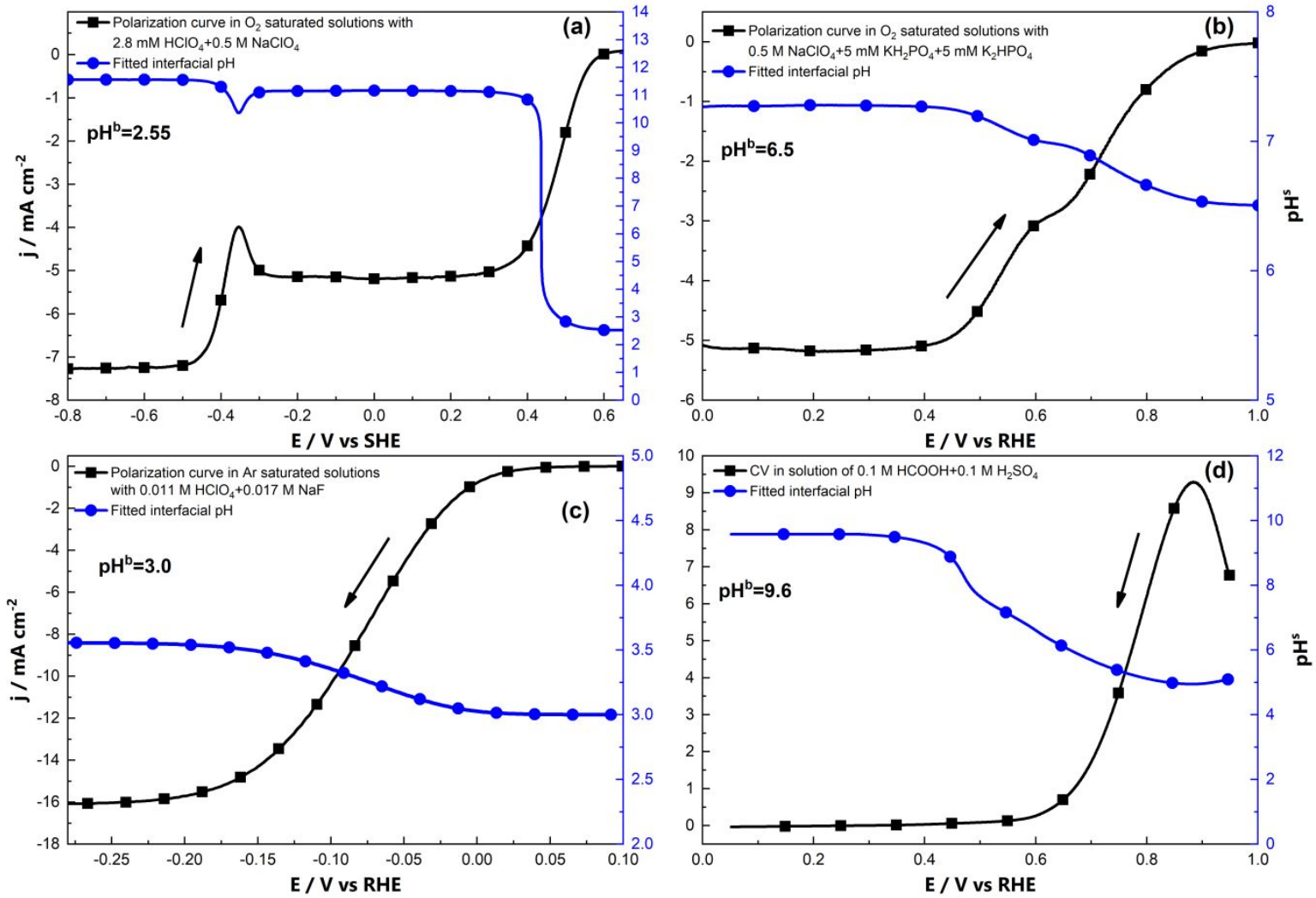

Figure S12. The $\mathrm{pH}^{\mathrm{s}}$ (blue line with circle) calculated according to $\mathrm{j}-\mathrm{E}$ curves (black line with square) measured by experiments: (a) Positive-going polarization curves for ORR and HER at pc-Pt disk electrode in $\mathrm{O}_{2}$ saturated $2.8 \mathrm{mM}$ $\mathrm{HClO}_{4}+0.5 \mathrm{M} \mathrm{NaClO}_{4}$ solutions with electrode rotation rate of $1600 \mathrm{rpm}^{30}$ (b) Positive going scan j-E curve of ORR on $\mathrm{Pt}$ (111) electrode in $\mathrm{O}_{2}$ saturated $0.5 \mathrm{M} \mathrm{NaClO}_{4}+5 \mathrm{mM} \mathrm{kH}_{2} \mathrm{PO}_{4}+5 \mathrm{mM} \mathrm{K}_{2} \mathrm{HPO}_{4}$ solution with $\mathrm{pH}=6.5,1600$ rpm (black line) and the variation of fitted interfacial $\mathrm{pH}$ with potential in this condition (blue line) (c) Negativegoing Polarization curve for HER on Pt(100) in Ar-saturated solution prepared with $0.011 \mathrm{M} \mathrm{HClO}_{4}+0.017 \mathrm{M} \mathrm{NaF}$ at $\mathrm{pH}^{\mathrm{b}}=3.0,2500 \mathrm{rpm} .{ }^{31}$ (d) Negative-going Polarization curve for FOR on Pt (111) (black line) and the corresponding interfacial $\mathrm{pH}^{\mathrm{s}}$ (blue line) as a function of the applied potential calculated by the model in solutions with the bulk $\mathrm{pH}$ of $9.6,1000 \mathrm{rpm}$.

For cathodic reactions such as HER and ORR, which consume protons, we will have $\mathrm{pH}^{\mathrm{s}} \geq \mathrm{pH}^{\mathrm{b}}$ (Fig.S12a-S12c). For 
such circumstance, the concentration gradient of proton decreases from the bulk solution toward the electrode surface. The corresponding $\mathrm{j}-\mathrm{pH}^{\mathrm{s}}$ curves are similar to those of anodic reactions, except that they have reverse evolution trend with the $\mathrm{pH}$ variation. In reality, if the buffer concentration is not high enough, one may observe significant $\mathrm{pHs}$ drift during reactions. An example for ORR at $\mathrm{Pt}$ in solutions with $5 \mathrm{mM} \mathrm{KH}_{2} \mathrm{PO}_{4}$ and $5 \mathrm{mM} \mathrm{K}_{2} \mathrm{HPO}_{4}$ with $\mathrm{pH}=6.5$ is shown in Fig.S12b. In order to sustain such high current, a con-centration of $1 \mathrm{M}$ for all the buffers are necessary. For reactions with current density higher than $100 \mathrm{~A} \mathrm{~m}^{-2}$, solutions with even $1 \mathrm{M}$ buffer may only sustain the pHs for solutions whose $\mathrm{pHb}=\mathrm{pKa} \pm 0.5$, one may need at least 7 buffer pairs whose $\mathrm{pKa}$ in the range from 3 to 11 to stabilize the interfacial $\mathrm{pHs}$.

In practice since only limited species can be used as buffer pairs (table S2), e.g., weak organic acid such as formic acid, acetic acid citric acid and so on or weak amine such as $\mathrm{R}^{-\mathrm{NH}_{2}}$, can be very active toward anodic oxidation or cathodic reduction in electrochemical environment, which may interfere the kinetic analysis of the reactions to be examined. The inert HF/F- pairs with a pKa of 3.45 may be good buffer for studies in mild acidic media. However, in solutions whose $\mathrm{pH}^{\mathrm{b}}>4$ even the concentration of such buffer pairs is above $0.5 \mathrm{M}$, the buffer capability is limited, as is evidenced by the diffusion limiting current for ORR and HER observed (Fig. S12c). Furthermore, since the buffer species may have limited solubility in aqueous solutions (e.g., preparing of buffer solutions with $1.0 \mathrm{M}$ concentration is not possible), it may not be possible to study the intrinsic $\mathrm{pH}$ effect for fast reactions in the broad $\mathrm{pH}$ range from 0 to 14 . In addition, side effects such as strong adsorption, reaction of the buffer species with the reactants or products, which may also interfere the investigation of the intrinsic $\mathrm{pH}$ effect. A typical example for this case is for HER, we know on Pt group metals, HER kinetics is very fast, the reaction current will easily surpass 1000 $\mathrm{A} \mathrm{m}^{-2}$. Under such high current densities, even with buffers of concentration above $1.0 \mathrm{M}$ the interfacial $\mathrm{pHs}$ in solutions within $\mathrm{pH}^{\mathrm{s}}$ range from 2 to 12 may not be sustained. For such circumstance, detailed kinetic analysis taking into account of the mass transport effect, the change of $\mathrm{pHs}$ and the consequent change of $\mathrm{E}_{\mathrm{eq}}$ for HER has to be corrected in order to derive the intrinsic $\mathrm{pH}$ dependence on HER kinetics.

Another complexity which is commonly encountered is that the reaction which we are interested in whose reactants or products pairs are also buffers, whose concentration near the electrode surface may change with pHs of the interface, reaction current and applied potential, due to the change of reaction pathways and consequent change of products selectivity. One typical example is formic acid oxidation, which has long been taken as a model reaction in electrocatalysis. The overall reaction of $\mathrm{HCOOH} / \mathrm{HCOO}^{-}$oxidation reaction in acidic media can be written as:

$$
\mathrm{HCOOH} \rightleftarrows \mathrm{CO}_{2}+2 \mathrm{H}^{+}+2 \mathrm{e}^{-}
$$




$$
\mathrm{HCOO}^{-} \rightleftarrows \mathrm{CO}_{2}+\mathrm{H}^{+}+2 \mathrm{e}^{-}
$$

In alkaline solution, formate oxidation reaction can be expressed as:

$$
\mathrm{HCOO}^{-}+\mathrm{OH}^{-} \rightleftarrows \mathrm{CO}_{2}+\mathrm{H}_{2} \mathrm{O}+2 \mathrm{e}^{-}
$$

Obviously, in acidic solutions, the concentration of $\mathrm{HCOOH} / \mathrm{HCOO}$ - near the electrode surface will change with $\mathrm{pH}^{\mathrm{s}}$ as well as the reaction current, which may in turn affect the contribution of reaction S1-S3 to the overall current measured (Fig. S12d). In addition, in solution with high $\mathrm{pH}, \mathrm{CO}_{2}$ produced may be easily hydrolyzed to form $\mathrm{CO}_{3}{ }^{2-}$, which may in turn change the $\mathrm{pHs}$ and equilibrium potential and reactants concentration of the respective reactions. The current plateau, i.e., the maximum FAO current does not change with $\mathrm{pH}^{\mathrm{b}}$ in the range from 4 to 10 observed previously may just be a consequence that the $\mathrm{pH}^{\mathrm{s}}$ under all these conditions dropped to a value close to 4 , since FAO is a reaction which produces protons, whose mass transfer away from the surface is much slower than its production. For details on the $\mathrm{pH}$ effect of FAO, please refer to https://authors.elsevier.com/a/1btnc_JcNEwB1. 